\title{
Plasma processing of dusts and residues
}

\author{
Dieter Neuschütz \\ Lehrstuhl für Theoretische Hüttenkunde, Rheinisch-Westfälische Technische \\ Hochschule Aachen, D-52056 Aachen, Germany
}

\begin{abstract}
The use of plasma furnaces for the recycling of metal scrap, of metallurgical residues and of fly-ashes from municipal solid waste (MSW) and sewage sludge (SS) incineration is reviewed. Aluminium dross, titanium scrap, spent automotive catalysts and stainless steelmaking dust are examples of current plasma melting applications. Whereever possible, hollow graphite electrodes tend to replace water-cooled metal torches. This trend also holds for plasma processing of MSW and SS incineration residues. In comparative pilot tests with these residues carried out with transferred-arc metal plasma torches and with graphite electrodes, respectively, no difference in processing behavior was observed. Under oxidizing conditions in the furnaces and in the off-gas systems, any de novo synthesis of dioxins was avoided and a vitrified slag, a small off-gas volume and a secondary fly-ash mainly containing volatile chlorides and sulfates were obtained.
\end{abstract}

\section{Introduction}

Thermal plasmas find increasing attention in materials processing for their high energy densities, low gas flow rates, ease of installation, and free choice of chemical potentials. Drawbacks are the costs for torches, electrodes, and power supplies, for plasma gases and electric energy. Industrial applications of thermal plasmas therefore depend on the balance between plasma-specific benefits and costs. This balance may change with time and location and cause plasma processes to emerge and disappear again.

\section{Steel}

\section{Scrap recycling}

In materials recycling, thermal plasmas are used very successfully in steelmaking from scrap in the electric arc furnace (EAF): In 1993, 223 mio $t$ of steel were produced in EAFs worldwide representing $31 \%$ of the total world production of crude steel (1). However, metallurgists speak of plasma furnaces only in the case of intentionally gas-stabilized electric arcs. Since EAFs are normally not operated with gas-stabilized arcs, they are not called plasma but arc furnaces. Occasionally, this arbitrary definition may give rise to confusion.

\section{Titanium}

For the recovery of titanium scrap, plasma melting processes have become well established (2). Apparently, the operation of an argon plasma system at atmospheric pressure is economically feasible when it competes with a high vacuum system.

\section{Aluminium}

The treatment of aluminium dross and scrap in plasma-heated rotary furnaces has been developed in order to replace the conventional rotary salt furnace process with its problems concerning the salt cake disposal $(3,4)$. Presently, Alcan is operating two plasma rotary furnaces with an annual capacity of $14,000 \mathrm{t}$ of dross in its Guillaume-Tremblay Works in Jonquière, Québec. The non-transferred plasma torch of the Westinghouse type is run with air. The dross is charged without preparation, and at the end of the batch operation the products are cooled down to $400^{\circ} \mathrm{C}$ under $\mathrm{Ar}$ atmosphere to keep $\mathrm{Al}_{2} \mathrm{O}_{3}$ and $\mathrm{AIN}$ formation low. The Al recovery is 80 to $90 \%$ with respect to metallic $\mathrm{Al}$ input. A second plasma rotary furnace plant was built by Plasma Processing Corporation in Ravenswood, West Virginia, with an annual capacity of $40,000 t$ of Al dross. PEC plasma torches with non-transferred arcs are operated with oxygen. By using pure oxygen, the $\mathrm{AIN}$ content decreases while the highly exothermic $\mathrm{Al}_{2} \mathrm{O}_{3}$ formation is promoted thus lowering the electric power demand. 

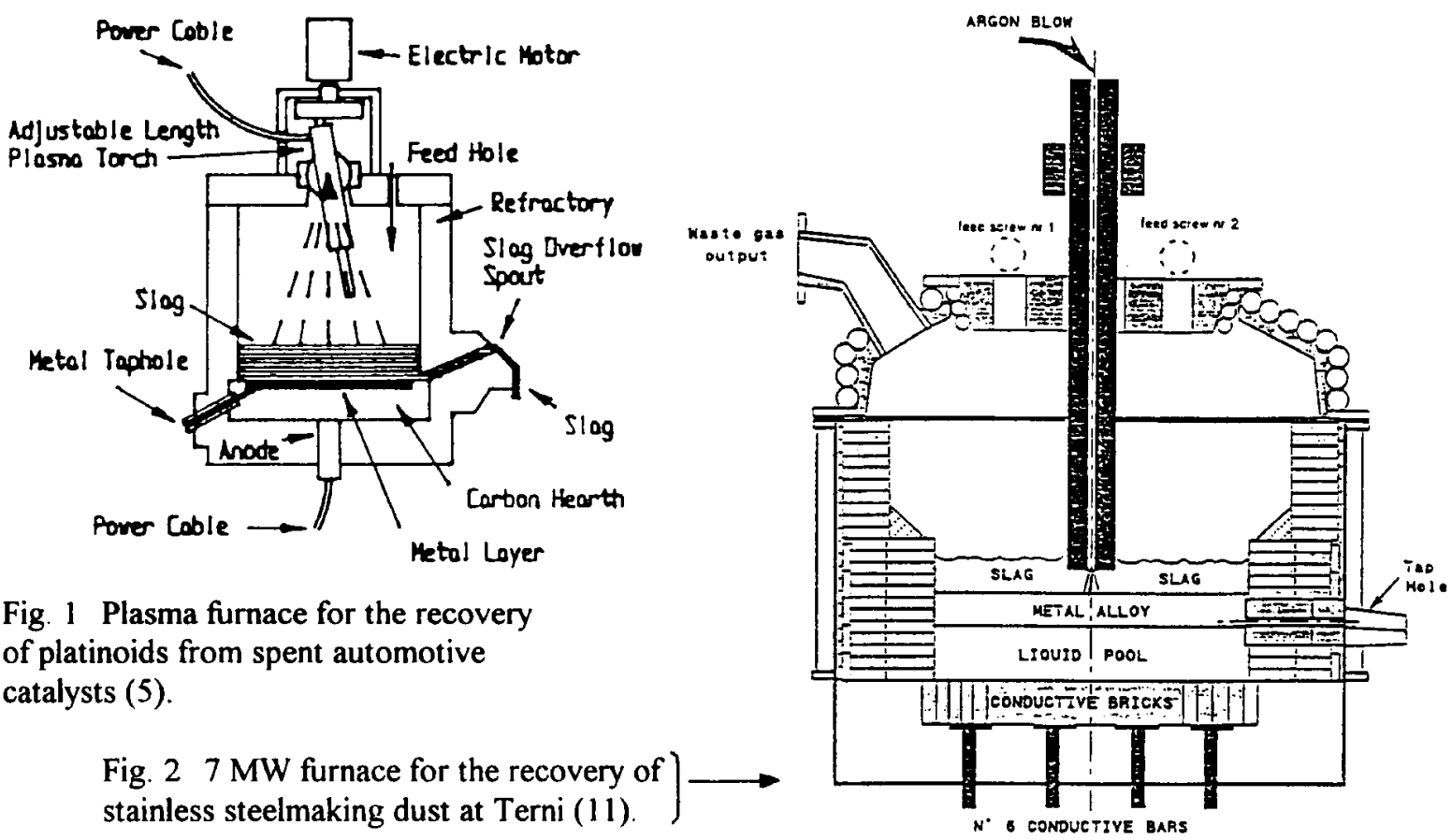

Fig. 1 Plasma furnace for the recovery of platinoids from spent automotive catalysts (5).

Fig. $27 \mathrm{MW}$ furnace for the recovery of stainless steelmaking dust at Terni (11).

Consequently, a rotary salt-free furnace has recently been taken into operation at Voerde, Germany, which is equipped with an oxy-fuel burner instead of a plasma torch. Apparently, the use of plasma torches in the case of $\mathrm{Al}$ dross processing is dependent on the local energy cost relations.

\section{Platinoids}

For the recovery of platinoids from spent automotive catalysts a plasma melting furnace has been in operation since 1984 at Multimetco, Anniston, AL (USA) with a feedrate of $>1 \mathrm{t} / \mathrm{h}$ and a recovery rate of $>98 \%$ of $\mathrm{Pt}, \mathrm{Pd}$ and $\mathrm{Rh}$. The catalysts are crushed, blended with lime and other additives, a molten calcium aluminate slag produced and the platinoids collected in a liquid carbon-saturated iron layer at the bottom. A DC cathode plasma torch (Tetronics) is installed through the roof, the anode being placed into the furnace hearth made of carbon, Fig. $1(5,6)$.

\section{Steel scrap fines}

With the aim of reducing the gas flow rate in a cupola furnace so that low-cost fine scrap like borings and turnings could be charged without excessive dusting, the $45 \mathrm{t} / \mathrm{h}$ cupola furnace at the foundry in Defiance, Ohio, was equipped with 6 plasma torches to superheat the blast. The cupola was commissioned in 1989 $(7,8)$. At Sept-Fons in France, a $20 \mathrm{t} / \mathrm{h}$ cupola was retrofitted with a plasma torch for blast superheating which permitted to feed the cupola with steel scrap instead of pig iron (9)

\section{Processing of steelmaking dust}

\section{Chromium steel}

The Scandust plant at Landskrona, Sweden, was built in 1984 and has successfully been operating as a smelter for non-agglomerated stainless steelmaking dust. The coke-filled shaft furnace is equipped with 3 plasma torches of $4 \mathrm{MW}$ each. A typical production figure is $35,000 \mathrm{t}$ dust/year (10).

In 1992, a plasma-arc furnace was installed at Terni, Italy, to process $20,000 \mathrm{t}$ /year of dusts and slurries arising from the two electric arc furnaces and the AOD vessel operating at Terni. The dust processing furnace, Fig. 2, is equipped with one hollow graphite electrode (cathode). Argon or nitrogen is blown through the hole in the graphite electrode to stabilize the arc. The dust is charged through two holes in the roof by means of 2 screw feeders together with $270 \mathrm{~kg}$ of coal and $60 \mathrm{~kg}$ of lime per $\mathrm{t}$ of dust. The alloy produced contains typically $11 \% \mathrm{Cr}, 2.5 \% \mathrm{Ni}$ and $5 \% \mathrm{C}$, while the volatile metals $(\mathrm{Zn}, \mathrm{Pb}, \mathrm{Cd})$ are recovered as dry dust rich enough in $\mathrm{ZnO}$ to be traded, and the slag ( $380 \mathrm{~kg} / \mathrm{t}$ alloy) is dumped. The single graphite electrode furnace is designed for $7 \mathrm{MW}$ and $20 \mathrm{kA}$. The diameters of the hollow electrode are 300 and $15 \mathrm{~mm}$. During commissioning, it was found most important to keep the feeding rate and the electric power in adequate balance (11). 
At British Steel Sheffield works, a 3 MW DC arc furnace is in operation for stainless dust processing. It is equipped with a solid graphite electrode, i.e. no plasma-stabilizing gas is added (12).

At the Chiba works of Kawasaki Steel, a pilot 1.5 MW DC plasma arc furnace has been operated with stainless steelmaking dust fed through the hollow graphite electrode by means of $\mathrm{N}_{2}$ carrier gas. The $\mathrm{Cr}$ and $\mathrm{Ni}$ yields were higher than those achieved by blowing the dust into the top and bottom blown converter without prior agglomeration (13).

\section{Ferronickel}

Based on the existing experiences with hollow-electrode DC arc furnaces for stainless dusts and for the production of ferrochromium from chromite fines (14), the Greek ferronickel producer LARCO, on the basis of an experimental study, came to the conclusion that the most feasible concept for recycling of their dusts and sludges $(1.2 \% \mathrm{Ni}, 8$ to $10 \% \mathrm{C} ; 230,000 \mathrm{t} /$ year $)$ was a large DC electric furnace with dust feeding through the hollow central graphite electrode (15). At present, the largest furnace operating as a smelter for fines is the $40 \mathrm{MVA} \mathrm{FeCr}$ furnace at Krugersdorp, South Africa, with a production rate of $6.3 \mathrm{t} \mathrm{FeCr} / \mathrm{h}$ (14), Fig. 3 .

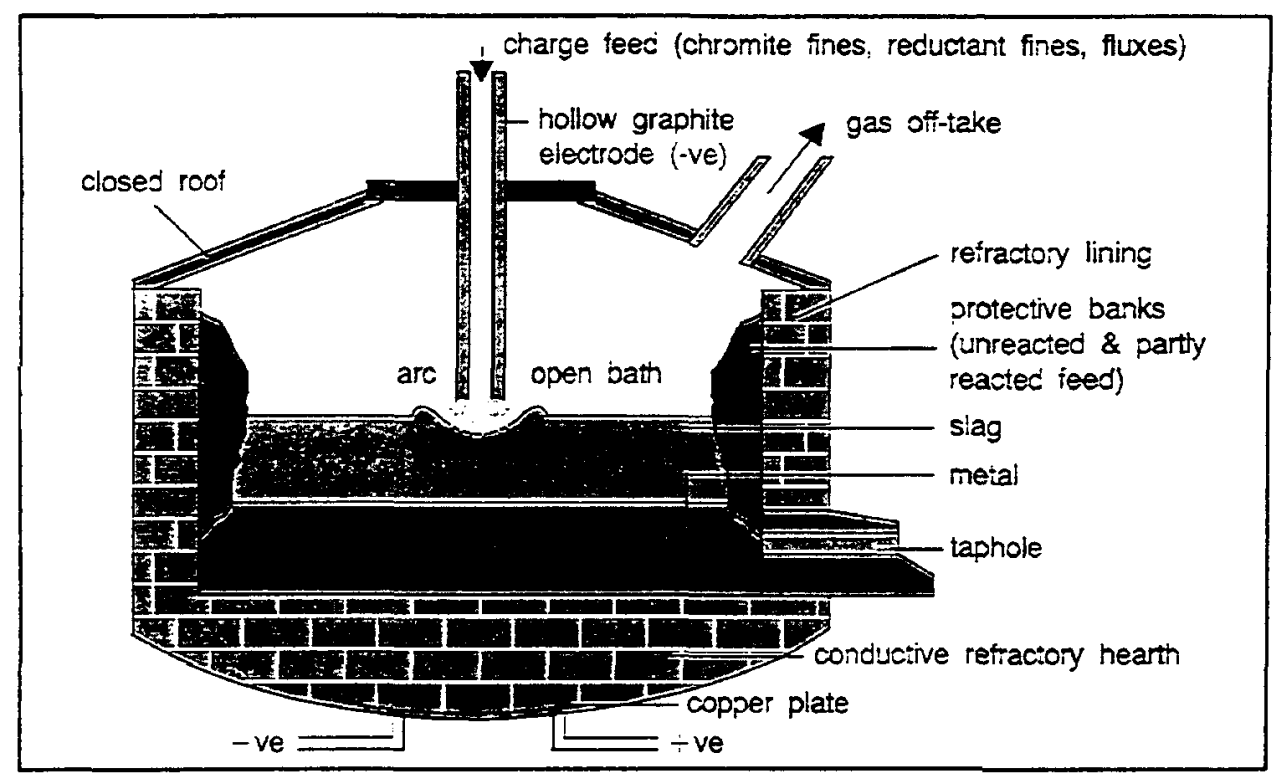

Fig. 340 MVA DC plasma furnace for ferrochromium production from chromite fines at Krugersdorp, South Africa (14).

\section{EAF steel}

Plasma furnaces have also been considered for processing normal EAF dusts containing relatively high amounts of zinc (16), which has to be separated before recycling the residue back into the steelmaking process. Therefore, the treatment consists of evaporating the zinc under reducing conditions and producing a $\mathrm{ZnO}$-rich flue dust which can be traded to the zinc industry. Since $\mathrm{ZnO}$ is more easily reduced than $\mathrm{Cr}_{2} \mathrm{O}_{3}$, the high temperatures required in stainless dust recycling are not really needed here. Consequently, nonelectric processes, like the rotary kiln, the rotating hearth or the circulating fluidized bed may be more adequate and economic methods than plasma smelting.

\section{Processing of solid residues from waste incineration}

\section{Aims of plasma processing}

Thermal plasmas have been taken into consideration for the processing of solid residues from municipal solid waste and sewage sludge incineration plants. The aim is to produce an inert vitrified slag to be used as road- or land-fill, a secondary fly-ash containing the volatile salts and oxides to be further treated and reused, and a small gas volume that can readily be cleaned. A number of pilot investigations have recently been carried out $(5,17-22)$, and first industrial furnaces started operating in Japan. In some cases metallic plasma torches are used $(18,21,22)$, in others graphite electrodes are preferred $(5,19,20)$. 


\section{Destruction of dioxins and furans}

In view of the requirement to destroy all dioxins and furans in the thermal process and to prevent any de novo synthesis during off-gas cooling, the proper choice of the oxygen potentials in and downstream the furnace plays an important role. From equilibrium considerations, the re-formation of dioxins is expected to occur at temperatures below $500^{\circ} \mathrm{C}$ and at relatively low oxygen potentials (23), Fig. 4. Therefore, the offgases should be quenched rapidly in the temperature range between 600 and $200^{\circ} \mathrm{C}$ in an atmosphere containing an excess of air, and the dust entrained with the off-gas should not contain any coal or soot particles which might locally create reducing conditions.

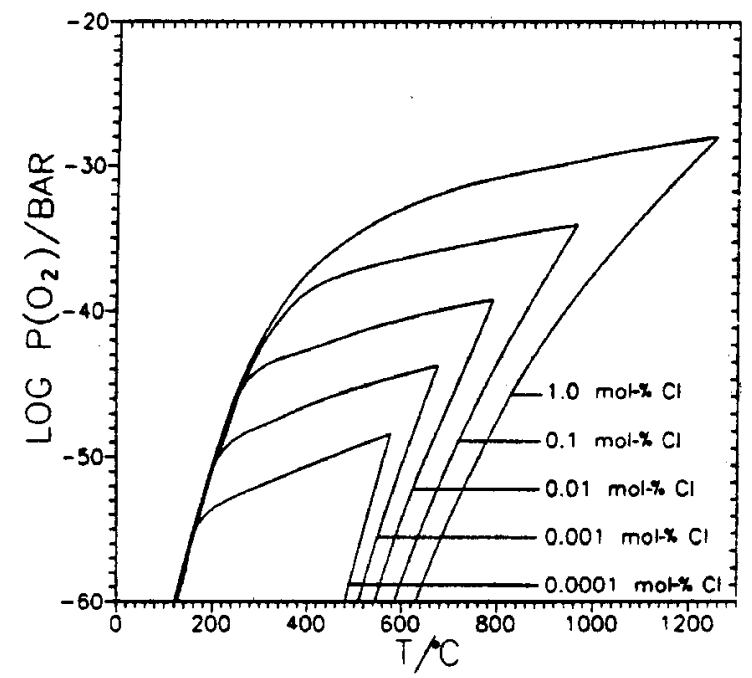

Fig. 4 Calculated regions in which the partial pressure of 2,3,7,8-TCDD reaches $0.1 \mathrm{ng} / \mathrm{m}^{3}$ for a $\mathrm{C} / \mathrm{H}$ mole ratio of $2 / 1$ and $\mathrm{Cl}$ contents from 0.0001 to $1.0 \mathrm{~mol}-\%$ in the system (23).

Metal torches versus graphite electrodes: pilot melting tests

In the melting furnace itself, a reducing atmosphere may be desirable to produce a liquid metal phase of the heavy metal oxides contained in the feed mix, but it will more likely be preferable to obtain only liquid slag which includes the non-volatile heavy metal oxides in a non-leachable form. In that case the melting process will take place in an oxidizing atmosphere. The use of graphite electrodes may therefore be limited by the environmental and product requirements. With this question in mind, results recently obtained in this laboratory (LTH) from pilot processing tests with dusts and ashes from municipal solid waste (MSW) and from sewage sludge (SS) incineration with metallic plasma torches are compared with tests carried out in a DC arc furnace with a hollow graphite electrode in similar scale in another laboratory (IME) of RWTH Aachen (20). The LTH equipment described in (21) was operated with 2 argon-stabilized tungstenelectrode plasma torches at $250-350 \mathrm{~kW}$, Fig. 5 .

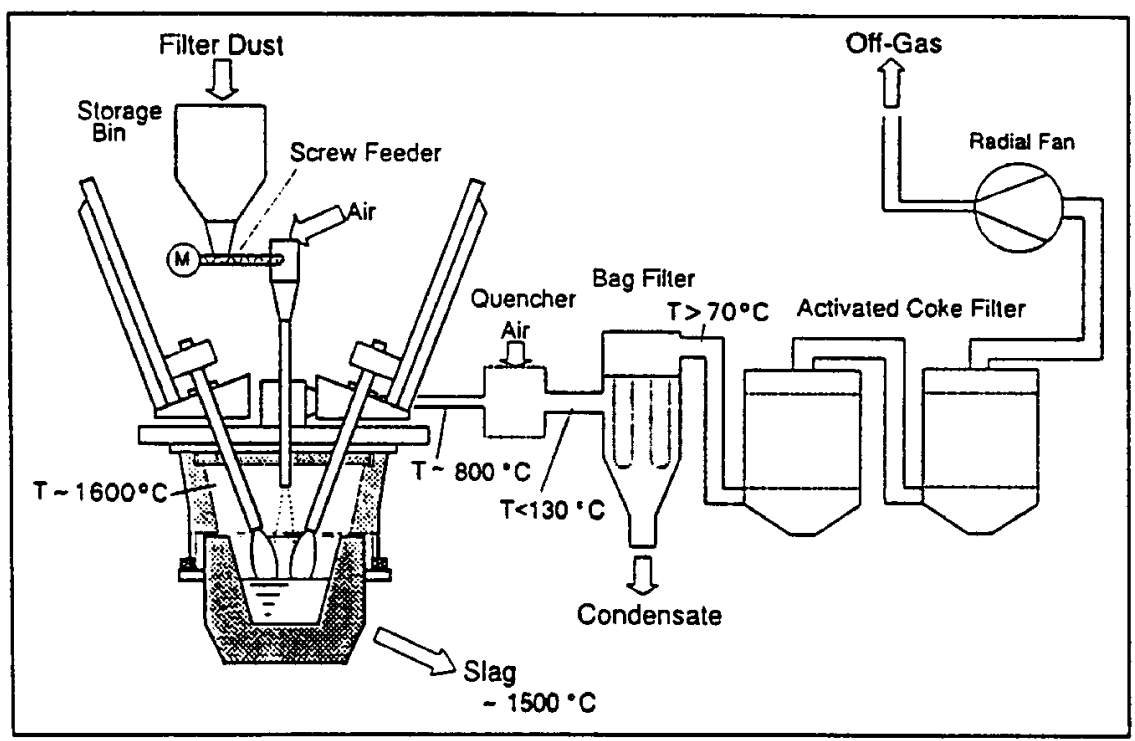

Fig. 5 Pilot plasma furnace at LTH (RWTH Aachen) with two metal plasma torches for AC operation, with dust feeding and flue-gas cleaning system (21). 
The IME furnace (20) had a central hollow graphite electrode (cathode) dipping into the slag, and a bottom anode. The dust was fed into the furnace through the electrode hole together with some carrier gas. The power rating was $450 \mathrm{~kW}$.

In both investigations, air was allowed to penetrate into the furnace to make the atmosphere oxidizing, and the off-gas was dry-quenched by large amounts of excess air. No reductant was added to the feed. Consequently, the formation of a metal phase could be avoided in the LTH test. IME reported the formation of a very small proportion of metal phase. Under similar non-reducing conditions, Ebara (Japan) melted sewage sludge residues in a $3 \mathrm{MW}$ plasma furnace and obtained about $10 \%$ of metal phase $(18,24)$. At LTH, a separate test was carried out with SS residues where a metal phase was deliberately formed by adding some carbon. In all these cases, the metal phases were mainly composed of 70 to $80 \% \mathrm{Fe}, 1$ to $10 \%$ $\mathrm{Cu}, 2$ to $7 \% \mathrm{P}$ and up to $1 \%$ each of $\mathrm{Ni}, \mathrm{Cr}, \mathrm{Sn}, \mathrm{Zn}$ and $\mathrm{C}$. Due to the high $\mathrm{Cu}$ and $\mathrm{P}$ contents such an alloy would not be an acceptable raw material for the steel industry. Therefore, it appears recommendable to avoid the formation of a metal phase altogether.

\section{Comparison of test results}

The following comparison comprises pilot test results obtained under oxidizing conditions for the melting of MSW fly-ashes and of SS grate-ashes, fly-ashes and a feed mix composed of both SS grate- and flyashes and spent foundry sand. In Table 1, the compositions of the different feed materials are listed. Table 2 contains the analyses of the slags produced, and in Table 3, the compositions of the secondary fly-ashes are summarized. Results from run $\mathrm{C}$ have been omitted because of abnormal entrainment of fines. Table 4 relates the relative amount of secondary fly-ash formed with the content of $\mathrm{Cl}$ and $\mathrm{SO}_{4}$ in the feed material.

By comparing these results with each other, the following conclusions may be drawn: The amount of secondary fly-ash is proportional to the content of anions in the feed capable of forming volatile compounds. Consequently, these fly-ashes are mainly composed of chlorides and sulfates. The alkali salts alone represent 65 to $70 \%$ of these fly-ashes, Table 5 . The degrees of volatilization observed for the different feed components were very similar in all tests. The average values are summarized in Table 6 . It appears that in most cases the degree of volatilization is related to the tendencies of the compounds to form volatile chlorides. Typically, the volatilized components were found as condensed matter in the fly-ashes except for $5 \%$ of the chlorine and $75 \%$ of the sulfur which remained in the off-gas as $\mathrm{HCl}$ and $\mathrm{SO}_{2}(20)$. More detailed considerations of the thermodynamics governing the evaporation and condensation processes in these multi-component systems are found in (21) and (25).

TABLE I: Compositions of feed materials

\begin{tabular}{|c|c|c|c|c|c|}
\hline $\begin{array}{c}\text { Components } \\
\text { wt-\%- }\end{array}$ & $\begin{array}{c}\text { A } \\
\text { MSW fly-ash } \\
\text { (LTH) }\end{array}$ & $\begin{array}{c}\text { B } \\
\text { MSW fly-ash } \\
\text { (IME) }\end{array}$ & $\begin{array}{c}\mathrm{C} \\
\text { SS fly-ash }\end{array}$ & $\begin{array}{c}\mathrm{D} \\
\text { SS grate-ash }\end{array}$ & $\begin{array}{c}\mathrm{E} \\
\text { SS residue mix }\end{array}$ \\
\hline $\mathrm{Al}_{2} \mathrm{O}_{3}$ & 8.3 & 12.9 & 9.47 & 9.9 & 8.15 \\
\hline $\mathrm{CaO}$ & 14.0 & 17.2 & 43.7 & 43.0 & 32.8 \\
\hline $\mathrm{SiO}_{2}$ & 17.1 & 27.5 & 15.0 & 22.6 & 35.9 \\
\hline $\mathrm{MgO}$ & 1.8 & 2.0 & 1.21 & 1.50 & 1.18 \\
\hline $\mathrm{TiO}_{2}$ & 1.3 & 1.2 & 0.51 & 0.58 & 0.46 \\
\hline $\mathrm{Fe}_{2} \mathrm{O}_{3}$ & 2.1 & 4.4 & 5.77 & 6.19 & 5.60 \\
\hline $\mathrm{Na}_{2} \mathrm{O}$ & 9.2 & 2.2 & 2.36 & 0.43 & 1.56 \\
\hline $\mathrm{K}_{2} \mathrm{O}$ & 10.5 & 2.5 & 0.77 & 0.67 & 0.72 \\
\hline $\mathrm{ZnO}$ & 7.1 & 3.8 & - & - & - \\
\hline $\mathrm{PbO}$ & 1.9 & 0.9 & 0.037 & 0.024 & 0.023 \\
\hline $\mathrm{P}_{2} \mathrm{O}_{5}$ & 1.4 & 0.9 & 7.74 & 8.16 & 6.02 \\
\hline C & 0.2 & 3.3 & - & - & - \\
\hline $\mathrm{Cl}$ & 12.0 & 4.0 & 2.6 & 1.3 & 1.41 \\
\hline $\mathbf{F}$ & 0.12 & 0.3 & - & - & - \\
\hline $\mathrm{SO}_{3}$ & 10.4 & 4.5 & 5.60 & 2.00 & 2.69 \\
\hline
\end{tabular}

SS residue mix $=45 \%$ SS fly-ash $+31 \%$ SS grate-ash $+24 \%$ spent foundry sand 
TABLE 2: Compositions of slags

\begin{tabular}{|c|c|c|c|c|c|}
\hline $\begin{array}{c}\text { Components } \\
\text { wt- } \%\end{array}$ & $\begin{array}{c}\text { A } \\
\text { MSW fly-ash } \\
\text { (LTH) }\end{array}$ & $\begin{array}{c}\text { B } \\
\text { MSW fly-ash } \\
\text { (IME) }\end{array}$ & $\begin{array}{c}C \\
\text { SS ny-ash }\end{array}$ & $\begin{array}{c}D \\
\text { SS grate-ash }\end{array}$ & $\begin{array}{c}\mathrm{E} \\
\text { SS residue mix }\end{array}$ \\
\hline $\mathrm{Al}_{2} \mathrm{O}_{3}$ & 24.6 & 17 & 24.8 & 18.0 & 20.3 \\
\hline $\mathrm{CaO}$ & 20.9 & 23 & 43.4 & 43.0 & 32.9 \\
\hline $\mathrm{SiO}_{2}$ & 26.8 & 35 & 14.7 & 21.4 & 32.5 \\
\hline $\mathrm{MgO}$ & 2.6 & 5 & 1.34 & 1.44 & 1.32 \\
\hline $\mathrm{TiO}_{2}$ & 2.7 & - & 0.47 & 0.56 & 0.43 \\
\hline $\mathrm{Fe}_{2} \mathrm{O}_{3}$ & 4.1 & II & 5.24 & 5.81 & 5.06 \\
\hline $\mathrm{Na}_{2} \mathrm{O}$ & 1.48 & 1.6 & 1.51 & 0.28 & 0.45 \\
\hline $\mathrm{K}_{2} \mathrm{O}$ & 0.37 & $<1$ & 0.07 & 0.08 & 0.12 \\
\hline $\mathrm{ZnO}$ & 0.68 & 0.1 & - & - & - \\
\hline $\mathrm{PbO}$ & 0.03 & $<0.1$ & 0.004 & 0.005 & 0.003 \\
\hline $\mathrm{P}_{2} \mathrm{O}_{3}$ & 0.87 & - & 6.94 & 7.19 & 5.20 \\
\hline S & 0.005 & $<0.3$ & 0.12 & 0.12 & 0.008 \\
\hline
\end{tabular}

TABLE 3:Compositions of secondary fly-ashes

\begin{tabular}{|c|c|c|c|c|}
\hline $\begin{array}{c}\text { Components } \\
\text { wt-\% }\end{array}$ & $\begin{array}{c}\text { A } \\
\text { MSW fly-ash } \\
(\mathrm{LTH})\end{array}$ & $\begin{array}{c}\text { B } \\
\text { MSW fly-ash } \\
(\mathrm{IME})\end{array}$ & $\begin{array}{c}\text { D } \\
\text { SS grate-ash }\end{array}$ & $\begin{array}{c}\text { E } \\
\text { SS residue mix }\end{array}$ \\
\hline $\mathrm{Na}$ & 12.2 & 9 & 10.4 & 18.1 \\
$\mathrm{~K}$ & 18.9 & 21 & 17.7 & 9.9 \\
$\mathrm{~Pb}$ & 4.3 & 5 & 1 & - \\
$\mathrm{Zn}$ & 8.6 & 17 & - & 38 \\
$\mathrm{Cl}$ & 31.0 & 31 & 32.3 & 16 \\
$\mathrm{SO}_{4}$ & 7.7 & 9 & 11.1 & 4.3 \\
$\mathrm{P}_{2} \mathrm{O}_{3}$ & 2.3 & - & 12.7 & 8.0 \\
$\mathrm{CaO}^{\mathrm{Al}_{2} \mathrm{O}_{3}}$ & 0.60 & 2.8 & 1.3 & 1.2 \\
$\mathrm{SiO}_{2}$ & 0.70 & 0.6 & 7.4 & 3.3 \\
$\mathrm{MgO}^{\mathrm{SnO}_{2}}$ & 1.0 & $<1$ & $<0.05$ & $<0.05$ \\
$\mathrm{Fe}_{2} \mathrm{O}_{3}$ & 0.10 & 0.3 & - & - \\
\end{tabular}

TABLE 4: Relation between secondary fly-ash formation and $\mathrm{Cl}^{*}$ and $\mathrm{SO}_{4}{ }^{-}$content of feed material

\begin{tabular}{|l|c|c|c|c|}
\hline & $\begin{array}{c}\text { A } \\
\text { MSW fly-ash } \\
\text { (LTH) }\end{array}$ & $\begin{array}{c}\text { B } \\
\text { MSW fly-ash } \\
\text { (IME) }\end{array}$ & $\begin{array}{c}\text { D } \\
\text { SS grate-ash }\end{array}$ & $\begin{array}{c}\text { E } \\
\text { SS residue mix }\end{array}$ \\
\hline $\mathrm{Cl}$ in feed (wt\%) & 12.0 & 4.0 & 1.3 & 1.4 \\
SO $_{4}$ in feed (wt\%) & 12.5 & 5.4 & 2.4 & 3.2 \\
\hline Relative amount of secondary fly-ash, \% & $30 \ldots 40$ & $10 \ldots 15$ & 3.5 & 5 \\
\hline
\end{tabular}

TABLE 5: Major coinpounds of secondary fly-ashes

\begin{tabular}{|l|c|c|c|c|}
\hline & $\begin{array}{c}\text { A } \\
\text { MSW fly-ash } \\
\text { (LTH) }\end{array}$ & $\begin{array}{c}\text { B } \\
\text { MSW ny-ash } \\
\text { (IME) }\end{array}$ & $\begin{array}{c}\text { D } \\
\text { SS grate-ash }\end{array}$ & $\begin{array}{c}\text { ES residue mix } \\
\text { Alkali chlorides and sulfates }\end{array}$ \\
Pb and Zn oxides & 15 & 67 & 60 & 65 \\
Phosphate, silicate, residual sulfate & 3 & 26 & 1 & 1 \\
Other oxides & 12 & 1 & 23 & 24 \\
\hline
\end{tabular}

TABLE 6: Volatilization degrees of the major feed components (average of tests A through E)

\begin{tabular}{|cc|cc|cc|}
\hline $\mathrm{As}, \mathrm{Cd}, \mathrm{Hg}$ & $>99 \%$ & $\mathrm{Cl}$ & $>98 \%$ & $\mathrm{Si}$ & $0.5 \ldots 2 \%$ \\
$\mathrm{Zn}$ & $295 \%$ & $\mathrm{P}$ & $4 \ldots 60 \%$ & $\mathrm{Ca}$ & $1 \%$ \\
$\mathrm{~Pb}$ & $95 \ldots 99 \%$ & $\mathrm{Cu}$ & $25 \ldots 60 \%$ & $\mathrm{Ti}$ & $<1 \%$ \\
$\mathrm{Na}$ & $40 \ldots 85 \%$ & $\mathrm{Cr}$ & $17 \ldots 23 \%$ & $\mathrm{Mg}$ & $<1 \%$ \\
$\mathrm{~K}$ & $70 \ldots 97 \%$ & $\mathrm{Fe}$ & $2.5 \ldots 4 \%$ & $\mathrm{Al}$ & $<1 \%$ \\
$\mathrm{~S}$ & $85 \ldots 99 \%$ & $\mathrm{Mn}$ & $2 \%$ & & \\
\hline
\end{tabular}


No difference in processing behavior was observed with regard to the torches used. No indications were found as to a de novo synthesis of dioxins neither with graphite electrodes nor with metal torches. Apparently, both systems are applicable for an oxidizing melting process of these incineration residues. A more substantial techno-economic comparison can only be made on the basis of full-scale operational data.

Acknowledgement: Financial support granted by the Minister für Wirtschaft, Mittelstand und Technologie des Landes Nordrhein-Westfalen within the TPMW program is gratefully acknowledged. The author is endebted to A. Stüber and M. Giesler for carrying out the experimental work at LTH and to Dr. A. Hauck for supervising it.

\section{References}

1. Jahrbuch Stahl 1995, Düsseldorf, Vol. 1.

2. Plasma Technology for a Better Environment, U.I.E. International Union for Electroheat, publ. U.I.E. Tour Atlantique, F-92080 Paris La Defense, 1992, pp. 57-71.

3. ibid, pp.53-56.

4. S. Lavoie, M. Litalien, A. Robitaille: Processing of dross in a plasma-arc heated furnace; 122th TMS Annual Meeting, Denver, Colorado, Febr. 1993.

5. J.K. Williams: High Temp. Chem. Processes 3 (1994), pp. 707-718.

6. $\operatorname{Ref}(2)$, pp. 74-75

7. Ref.(2), pp.41-45.

8. D.P. Kanicki: modern casting, Dec. 1989, p. 21.

9. M. Labrot in: Proc. Conf. „Plasma for Industry and Environment“, 25-27 Sept. 1990, Oxford (England), BNCE.

10. B. Johansson, U. Lofgren in: Ref. (9).

11. F. Bruno, J.J. Hunt, E. Repetto: ILSERV process for the treatment of EAF and AOD dusts, Proc. „Process - Material Innovation in Stainless Steel Products“, Florence, Italy, Oct 11-14,1993.

12. $\operatorname{Ref}(2)$, p. 27.

13. Y. Koshimoto et al. in: Ref (9).

14. M. Ford, J.F. Oosthuizen: The production of ferrochromium in a 40 MVA DC plasma furnace; INFACON 7, Trondheim, Norway, June 1995, eds: Tuset, Tweit and Page; publishers: FFF, Trondheim, Norway, 1995, pp. 263-272; D.D. Slatter: Technological trends in chromium unit production and supply, ibid pp. 249-262.

15. I.E. Alexopoulou et al.: Erzmetall 47 (1994), pp. 562-57I and pp. 651-657.

16. Ref(2), pp. 17-39.

17. $\operatorname{Ref}(2)$, pp. $111-130$.

18. H. Jimbo et al: : Plasma melting process of incinerator residue, Inst. Adv. Mater. Process. Report No. 2111, Bull. Inst. Adv. Mater. Proc., Tohoku Univ., 49, Dec. 1993, Sendai, Japan (in Japanese).

19. C. Oberlin: Plasma processes for industrial applications - state of research and development activities undertaken by EDF, High Temp. Chem. Processes 3, December 1994.

20. G. Grund et al.: Aufarbeitungsmöglichkeiten dioxinhaltiger Flugstäube, paper presented at EMC ' 94 (Second European Metals Conference) 14-18 June 1994, Freiberg and Dresden, publ. by GDMB Informationsgesellschaft, Clausthal-Zellerfeld, 1994.

21. A. Stüber, A. Hauck, D. Neuschütz: Processing tests of filter dusts from a waste incineration plant in a $600 \mathrm{~kW}$ plasma melting furnace, in: Thermal Plasma Processes TPP 3, VDI Berichte 1166, ed. by D. Neuschütz, publ. by VDI Verlag Düsseldorf 1995, pp. 583-590.

22. H. Klein: Thermische Aufbereitung toxischer Stäube mit Plasmatechnik; elektrowärme international $\underline{50}$ (1992) B2, pp. 120-126.

23. P.J. Spencer, D. Neuschütz: Thermodynamic conditions for the formation of dioxin; Chem. Eng. Technol. 15 (1992) 119-123.

24. H. Jimbo, T. Amemiya, T. Kawase: Recycling of incinerator residues in a plasma melting furnace, Kagaku Souchi, Special Issue, July 1995, pp. 63-68 (in Japanese).

25. F. Kassabji, P. Frugier: Analyse thermochimique de la vitrification du REFIOM par les procédés hautes temperatures; Journées d'Etude March 29, 1995, Societé française des thermiciens, EDF, Moret sur Loing, France. 